inventors, Messrs. Thomas and Gilchrist, and its great importance lies in the fact that it enables Besscmer steel and a very pure homogeneous iron to be produced from the poor class of phos. phoric iron ore which abounds in the Cleveland district and also in the basin of the Saar, and in Lorraine and Luxembourg, which ores have not bitherto been available for the production of steel, on account of the difficulty of eliminating the phos. phorus, the presence of which element is well known to be highly detrimental to the quality of the steel. To the Germans this invention is possibly of greater value than to ourselves, on account of the prevalence with them of the poorer class of orc, and the comparative scarcity of hematite.

At the present moment five German companies are working the Thomas-Gilchrist process, and in the course of a few months many others will be in a position to follow suit.

Herr Massenez gives in his paper a series of chemical analyses, showing the composition of the metal at different stages during the blow. The information contained in these tables is also exhibited graphically by diagrams, in which the quantities of the various elements at the different stages are represented by the ordinates of curves. These "show that so long as the silicon is in combustion the phosphorus not only is not attacked, it actually itcreases. First of all, as is well known, the silicon is attacked, and is reduced to a mere trace at the expiration of two minutes. A portion of the carbon burns off at the same time with the silicon; however, only after the silicon is reduced does the carbon curve descend rapidly. The manganese curve is from the commencement to the end of the blow regularly decensional, showing that this body oxidises but slowly. The small quantity of copper disappears after the end of the first minute's blow. Surprising is the fact that the sulphur-curve slowly rises till the commencement of the after-blow, and then only decreases partially, or very slowly, the latter end of the same. The phosphorus is energetically consumed in large quantities after decarbonisation has taken place, and its combustion is the cause of the high tempcrature at the end of the process. At the commencement of the blow, and during the time the silicon is oxidising, the phosplorus increases in the metal in the proportion as caused by the lessening of the volume of pig iron through the combustion of silicon, manganese, and carbon. After the reduction of the silicon, and daring the period the carbon is reduced from 2.72 per cent. to 0.16 per cent., only a fraction of the carbon disappears (from $1 \cdot 32$ per cent. to $1 \cdot 18$ per cent.); afterwards the very rapid combustion of this body takes place, leaving only a trace of the same, a reaction which characterises the whole process."

It is satisfactory to learn from this paper that the chemistry of the process is now thoronghly understood, and that the only difficulties which remain to be overcome are of a purely mechanical nature, and are principally due to the shortness of life of the converter bottoms. The discussion which followed was fully equal in interest to the paper itself, and was taken part in by most of the leading members of the Institute. It bore principally upon the commercial side of the invention, which has hitherto been its weak point. We learn, however, that well-founded hopes are entertained fthat this last difficulty in the way of a gcneral introduction of the process is in a fair way of being removed.

In our last review of the proceedings of this Institute we noticed a paper by Prof. Akerman, on "The Hardening of Iron and Steel." 'This paper, which was taken as read at the spring meeting, was discussed at Diisscldorf. Most of the opinions expressed were necessarily of a rather speculative character, for very little is really known as to the rationale of hardening and tempering. Many eminent authorities seemed, however, to be agreed that carbon exists in iron and steel in three separate forms, and not in two only, as has litherto been supposed, and that the hardening is due only to one of these forms. A point of great practical importance was referred to by Mr. Adamson, viz., the prevalent practice of endeavouring to strengthen steel by tempering in oil. This practice was strongly condemned by Mr. Adamson. He maintains that the dipping in oil, though it may increase the tensile strength of the metal, impairs its clasticity and ductility. We commend this opinion to the attention of the authorities at Woolwich Arsenal. It is well known that the steel barrels of all our guns are tempered by immersion in oil, and if Mr. Adamson's statements be correct, it is not to be wondered at that so many disappointing failures have taken place.
The last paper to which we shall refer dealt with the subject of iron permanent way. It contained an account of the experience obtained on the German state railways of the use of iron instead of timber for sleepers. There are few subjects of greater importance to ironmasters than this substitution of iron for woodwork in the permanent ways of railways, for the amount of metal which would thus be consumed is almost incalculable. The paper, which was read by Privy-Councillor Grüthcfein, embodies much valuable information as to the different systems of iron permanent way at present in use. From it we learn that there are at the present moment 1,542 kilometres of line in Gernany laid with the new description of sleeper, and that the results obtained are so satisfactory that the system is being continually extended. It is interesting to notice that in Germany the new sleepers are mostly laid on the longitudinal plan, a system which bas not given satisfaction in this country. In the discussion which followed, the opition was strongly stated by English engineers that longitudinat sleepers would be absolutely incapable of withstand. ing the cffects of the very heavy and fast traffic of the main lines in this country.

In conclusion we must congratulate the Iron and Steel Insti. tute on the extended sphere of usefulness and the cosmopolitan character which it has gained by going ont of the beaten track, and holding an antamn meeting on the Continent.

\section{ANNUAL CONGRESS OF THE GERMAN ANTHROPOLOGICAL SOCIETY}

TIIE EIeventh General Meeting of the German Anthropological Society was beld at Berlin during the past month, Prof. Virchow taking the chair and acting as president at each of the six sittings. At the opening sitting, after speeches by Herr von Gossler and the President, in which they reviewed the past and the present condition of the Society, and notably drew attention to its aims and its dchievements, Horr Friedel gavera short exposition of his paper."On Prehïstoric Discoveries made in Berlin and its Neighbourhood." This was followed by an interesting address from Dr. Schliemann respecting the site of Troy. He re-stated his now well-kmown convictions, "and gave considerable cvidence in support of the belief that Homer's Troy was not merely a mythical town, but that it had once actually filled a place in the world's history. "I wish," said the Doctor, "I wish that I were able to prove Ilomer to have been an eye-witness of the Trojan war. But unfortunately this is impossible. In his day swords were in general use as a weapon, and iron well known as a metal; in Troy, again, swords wawe anheard of, while of iron the inhabitants knew nothing whifever. So, too, the manners, the customs and the general civilisation which he describes are of an epoch that is centuries later than the one to which the results of my excavations belong. Homer presents to us the legend of Ilium's tragic fate in the form which it had been handed down to him by the bards who had gone before; and, as we have already seen, he invests the traditional account of the war and of the fall of Troy with the colouring of the time in which he lived. Yet he was not without personal knowle lge of the actual localities, for his descriptions (both the general one of Troy itself, as also of the plains of Troy in particular) are, if taken as a whole, quite accurate and truthful." At the close of his address, Dr. Schliemann announced his intention of commencing a serics of excavations on the site of Orchomenos in Bocotia, the prehistoric capital of the Minyans, on his return to Athens, the Greek Government having accorded him full permission to do this.

At the second sitting, on Angust 6, after a short address by the President, Prof. Ranke spoke at some length upon the subject of German cthnology and anthropology, pointing out the distinct advance that these sciences had made, and citing, as helps to study, the several important werks which had appeared in the country by Lindenschmit, Arnold, Bracht, Poppe, Genthe, v. Sadowski, and other distinguished anthropologists. He specially called attention to the progress that had been made in the science of craniology, it being now nearly olways possible to distinguish between a male and a female skull. Prof. Virchow then bricfly put forward the proposition that the next (the twelfth) session of the Society should be held at Ratisbon, a town which, for many reasons, he thought was well fitted to serve such purpose. This proposal was carried nnanimously; and after an address by Herr Friedel the meeting was adjourned. 
Herr Handelmann, at the third sitting, read a valuable paper upon the prehistoric fortresses and earthworks of which traces remain in the Schleswig-HIolstein district. This was followed by an address from Dr. Koehl respecting the excavations and prehistoric discoveries that had been made at Meckenheim, near Bonn. Dr. Mehlis, Herr von Jazdzewski, and others also addressed the meeting.

On the following day, August 9, Dr. Kollmann laid before the Society numerous important statistics with reference to the ethnology of Switzerland, and in connection with the division of blond and brunette types, showing where such division may be found to occur. Dr. Tischler's paper upon recent prehistoric discoveries made at Dolkeim, in East Prussia, was also listened to with very great interest.

At the fifth sitting, Herr Fraas, speaking on behalf of the Cartographical Commission, proceeded to show in how far this institution had been of service to the cause of anthropology; he also dwelt upon the need for drawing up accurate maps of the different districts and localities in which prehistoric discoveries had been or would be made.

Pfarrer Dahlem of Ratisbon afterwards addressed the assembly, his subject being, Ratisbon in its relation to archæology past and present. Speaking of the antiquity of the town, he rejected as fabulous the belief of chroniclers that it had been built before the foundation of Rome, or even of Troy, although its early existence is proved by two old Roman finds, the one a military diploma of the time of Marcus Aurelius, dating from A.D, 166 , and the other a large block of stone three metres in length and one metre in height, being a fragment of the porta principalis of the city. The inscription on this latter clearly sets forth that Marcus Aurelius and his son Commodus had erected the vallum cum portis et turribus. As this inscription, from the titles given to the Emperor, was engraved upon the gate either immediately before or closely following the death of Marcus Aurelius, it is indisputable that in the years preceding that time, between about A.D. 170 and 180 , the town was built by one of the three legions that the Roman Emperor had recruited from Italy in order to quell an invasion in that part of Germany now termed Bavaria. That this was the probable date may be inferred from the belief that the inscription would surely not have been added until the whole were completed. The lecturer clearly showed that Ratisbon was a town of very great historic interest; the choice of it as a meeting-ground for the next annual conference of the German Anthropological Society is thus in every way a most desirable one.

At the sixth sitting, Prof. Bastian, who was warmly welcomed by his colleagues upon his return from a two years' period of travel, delivered a very eloquent address, in which he pointed out the many difficulties in connection with the study of ethnology and anthropology, and warned his hearers against drawing a priori conclusions in dealing with a science that needed such minute and careful research, where the field was so vast, so limitless a one, and where no clne, however slight, could ever afford to be lightly set aside. "We are occupied to-day," said he, in conclusion, "with a science that as yet is in its cradle, one over which the shadow of many centuries must sweep ere it can reach manhood, but which will then clearly and completely set forth that which has been termed ' the knowledge of man about man,' a science which, though it does not solve the deepest problems of our existence, will yet throw a partial light upon them. And in its construction we are merely builders and masons, content if we may but do our humble part towards this one object, the completion of so great and wonderful a work."

After speeches by Dr. Henning, Dr. Montelius, and others, Prof. Undset of Christiania gave an interesting account of the recently-discovered Viking ship that has been excavated from a large burying-mound at Sandefjörd, in the vicinity of Christiania. The mound in question has always been termed "The King's Mound" (Königshirgel), and until last winter no excavations had ever been attempted there. Under the superintendence of Prof. Nicolaysen, however, operations were then commenced, which resulted in a most interesting and extraordinary discovery. Beneath the hill was found a large ship, seventy-five feet in length, sixteen feet in breadth, and about seven or eight feet in depth. In it a kind of vault had been built, wherein were deposited the remains of some valiant sea-king who, may be, had won his people's love and reverence. The ship had been buried fully rigged, with masts, cordage, sails and rudder all complete, the entire timbers being in a wonderful state of preservation, owing to the fortunate circurastance that the mound had been con- structed of a moist clay. In all its details the vessel appears to have been most beautifully finished, and there is no lack of ornamentation. In the hold, together with the human remains, were found the bones of several horses and dogs that had evidently been buried with their master. Prof. Undset considered that the burial must have taken place some time during the tenth century. The ship was conveyed to Christiania, where it was at once placed in the University Museum for Prehistoric Antiquities in that city. Several photographs have been taken of it, and the results of further investigation and research re. specting it will shortly be published in a longer and more detailed form.

Herr Ranke then delivered an address upon the prehistoric discoveries that had been made in the caves of Upper Franconia; and Prof. Schaaff hausen of Bonn also spoke with reference to important researches made in the caves at Gerolstein, at L.etmathe, and Eiserfey. The interest of this sitting-the final one - centred in the speech of Herr Brugsch Bey, the distinguished Egyptologist, who, in the course of it, pointed to Egypt as a rich and valuable field for prehistoric research.

\section{OUR ASTRONOMICAL COLUMN}

SOUTHERN VARIAbLe Stars. - In the Uranometria Argentina amongst the large number of stars indicated as variable, we find twelve to which Dr. Gould has applied the letters of Argelander's nomenclature, their fluctuations having been determined with greater certainty than some others. The following is a list of these objects arranged in order of right ascension :-

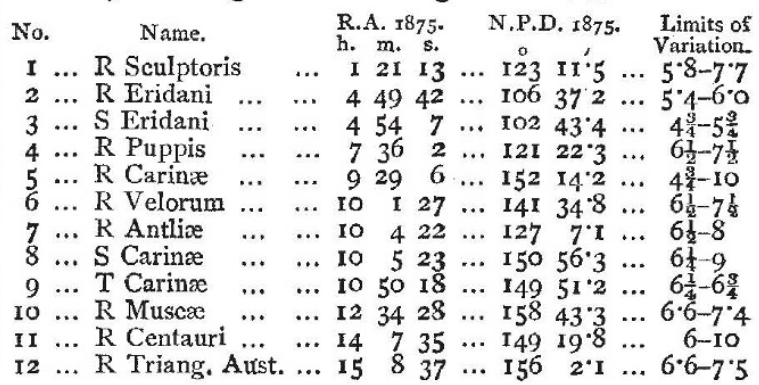

I. Gould describes this as "one of the most brilliantly coloured stars in the heavens"-an intense scarlet, which remains un. changed through all the stages of its light. Maxima occurred early in December, 1872 , and in January, 1874 . Period about 207 days with symmetric light -curve.

2. Variation independently shown by the estimates of three observers, to the extent of more than half a magnitude ; red.

3. 64 Eridani-" certainly variable;" Bessel calls it $8 \mathrm{~m}$. in his zones, which Gould conjectures may be owing to clouds, or ? a misprint.

4. Though appearing to the naked eye and even with the opera glass as a single star is in fact a cluster of faint stars $=3094$ of Herschel's Cape Catalogue. There is only one star in it brighter than $8 \frac{1}{2}$, and Gould assumes that the variations of brilliancy are due to this star alone. The object is Lacaille 2916.

5. Lacaille 3932, noted by him 7m. on March 3, 1752. The intervals between the maxima determined at Cordoba, are respectively 320,306 , and 323 days; the minimum appears to take place considerably more than half a period later than the maximum; red in all stages even while at the tenth magnitude. No epoch of maximum is given.

6 . $\mathrm{R}$ Velorum. The variable character is beyond question. It is Lacaille 4156.

7. R Antlix. Estimated near the brighter limit March I9, I871, and in May, 1872; near the fainter one April 28, 1873, and June 14,1874 .

8. S Carinæ. A reddish star, Lacaille 4189. On May 2I, 1874 , it was 6.3 , and in May, $1877,8 \frac{3}{4}$, but sufficient observations have not yet been made to determine the law of variation.

9. T Carinæ. Period not yet ascertained. Lacaille 4530.

Io. R. Muscæ. Varies through nearly a magnitude in not far from $2 \mathrm{rh}$. $20 \mathrm{~m}$, the minima preceding the maxima by nine hours; its period is therefore the shortest yet detected amongst the variables, and it becomes an object of unusual interest. At midnight on September 25,1872 , the star was estimated equal 